\title{
PTX3 wt Allele
}

National Cancer Institute

\section{Source}

National Cancer Institute. PTX3 wt Allele. NCI Thesaurus. Code C119681.

Human PTX3 wild-type allele is located in the vicinity of $3 \mathrm{q} 25$ and is approximately $7 \mathrm{~kb}$ in length. This allele, which encodes pentraxin-related protein PTX3, plays a role in both complement activation and inflammation. 